\title{
Low Back Pain as the First Presentation of Hürthle Cell Carcinoma of Thyroid
}

\section{Lombalgia como a primeira manifestação do carcinoma de células de Hürthle}

\author{
Ricardo Vieira Botelho ${ }^{1}$ Matheus Fernandes de Oliveira ${ }^{2}$ Sílvio Tenório Gameleira Filho ${ }^{2}$ \\ Jânio Alves Ferreira ${ }^{2}$ Leonardo Rafael Takahashi ${ }^{2}$ José Marcus Rotta ${ }^{1}$ \\ ${ }^{1}$ Neurosurgeon, Department of Neurosurgery, Hospital do Servidor \\ Público Estadual de São Paulo, IAMSPE, São Paulo, Brazil \\ Address for correspondence Matheus Fernandes de Oliveira, MSc, Av. \\ Luís Góis 1333, apto 23, Vila Mariana, São Paulo, São Paulo, Brazil, CEP \\ 2 Neurosurgery Residency Program - Department of Neurosurgery - \\ 04043-150 (e-mail: mafernoliv@yahoo.com.br).
} Hospital do Servidor Público Estadual de São Paulo, São Paulo, Brazil

Arq Bras Neurocir 2015;34:53-55.

\begin{abstract}
Hürthle cell carcinoma is a rare variant of differentiated thyroid cancer and occasionally generates distant metastases. There are few reports of Hürthle cell carcinoma metastases to the vertebral column and none with sacral involvement. Here, we report a 48-year-old woman with a 2-year history of moderate low back pain, alleviated with analgesic medication. Her previous medical files were unremarkable. She performed medical evaluation, and a magnetic resonance of lumbar spine revealed a solitary hypointense $\mathrm{T} 2$ lesion on the left lamina of S1. The patient was submitted to percutaneous biopsy that displayed carcinomatous pattern compatible with Hürthle cell carcinoma of thyroid. After that, she was submitted to thyroid ultrasound that

\section{Keywords}

- low back pain

- spinal diseases

- neoplasm metastasis

\section{Resumo}

Palavras-chave

- dor lombar

- doenças da coluna vertebral

- metástase neoplásica showed a nodule. Even in the presence of metastases, patients with Hürthle cell carcinoma usually have a relatively good prognosis. We discuss aspects of the diagnosis, management, and surgical treatment of metastatic Hürthle cell carcinoma in reference to the literature.

O carcinoma das células de Hürthle é uma variante rara do câncer de tireoide. Existem poucos relatos de metástases dessas lesões para a coluna vertebral. Nós relatamos o caso de uma paciente de 48 anos com história de dois anos de lombalgia. Ela era previamente hígida. A avaliação radiológica evidenciou uma lesão solitária na lamina esquerda de S1. Após biópsia percutânea, foi diagnosticado o carcinoma, sendo diagnosticada também uma lesão sincrônica em tireoide. Nós discutimos os aspectos, clínicos, radiológicos e de tratamento no caso supracitado.
\end{abstract}

\section{Introduction}

Thyroid cancer is the most common tumor of the endocrine system. ${ }^{1,2}$ It is usually divided in three major subtypes: papillary, follicular, and medullary. The prognosis of patients with differentiated thyroid cancer is excellent and 10-year survival is more than $90 \%{ }^{1}$ Dissemination of thyroid cancer is primarily via regional lymph nodes and metastatic pulmonary disease may develop, followed by bone involvement. ${ }^{1}$ received

December 10, 2013

accepted

November 1, 2014
Dol http://dx.doi.org/

$10.1055 / \mathrm{s}-0035-1547379$.

ISSN 0103-5355.
Copyright (c) 2015 by Thieme Publicações License terms

Ltda, Rio de Janeiro, Brazil 
Hürthle cell carcinoma is a rare variant of differentiated thyroid cancer and occasionally generates distant metastases. $^{2-4}$ There are few reports of Hürthle cell carcinoma metastases to the vertebral column and none with sacral involvement. ${ }^{2-4}$ We report a unique case of Hürthle cell carcinoma metastasis to sacral spine presenting with low back pain.

\section{Case Description}

We report a 48 -year-old woman with a 2-year history of moderate low back pain irradiating to posterior and medial left thigh, being initially alleviated with common analgesic medication and physical therapy. After 1 year, she returned in use of paracetamol and codeine with a milder sustained pain that increased at walking or long standing up.

Her previous medical files were unremarkable. At that moment, she denied fever of weight loss. She underwent new medical evaluation. Her physical examination, including neurologic status, was normal. Because of long course of pain, she was submitted to radiologic evaluation. Lumbar and sacral spine radiographs were initially of limited help, but a lumbar and sacral tomography immediately revealed an osteolytic lesion in the left S1 lamina, invading the vertebral canal. A magnetic resonance imaging revealed a solitary hypointense $\mathrm{T} 1$ and $\mathrm{T} 2$ lesion on the left lamina of $\mathrm{S} 1$, which homogeneously enhanced after endovenous gadolinium injection (-Fig. 1). Among possible diagnosis, tumoral etiology was considered, and because of topography and image, the main hypothesis included sacral chordoma, lymphoproliferative neoplasms, and metastatic lesions. To determine the nature of lesion, the patient was submitted to percutaneous biopsy guided by fluoroscopy, without any surgical complications.

Pathological findings were compatible with an oncocytic solid-glandular neoplasm. Immunohistochemistry showed expression of tireoglobulin, CK7, and CK19, a pattern compatible with Hürthle cell carcinoma of thyroid (-Fig. 2). Immediately after diagnosis, she was submitted to thyroid ultrasound that revealed a solitary, solid, lobulated, heterogeneous, predominantly hypoechoic with hyperechoic foci nodule, with peripheral and central vascularization in the middle third of right thyroid lobule. She was forwarded to Neck and Head Surgery Service for further approach.

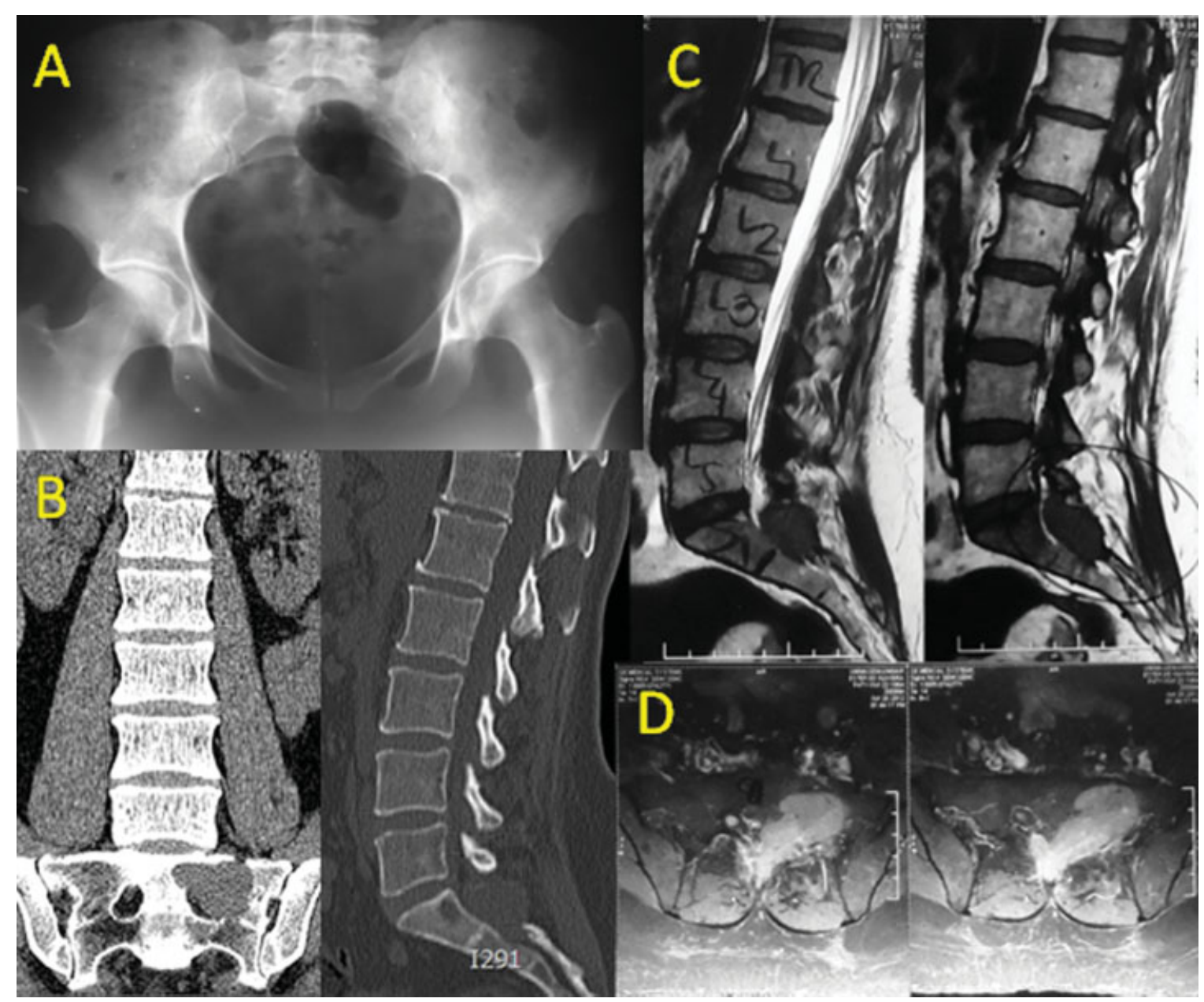

Fig. 1 Radiologic evaluation. (A) A pelvic radiography with interference of gas in the colon. (B) Lumbar and sacral tomography revealing an osteolytic lesion in left S1 lamina, invading vertebral canal. (C) Sagittal magnetic resonance imaging displaying a solitary hypointense T1 and T2 lesion on the left lamina of S1. (D) Axial magnetic resonance imaging on the left lamina of S1 homogeneously enhancing after endovenous gadolinium injection. 


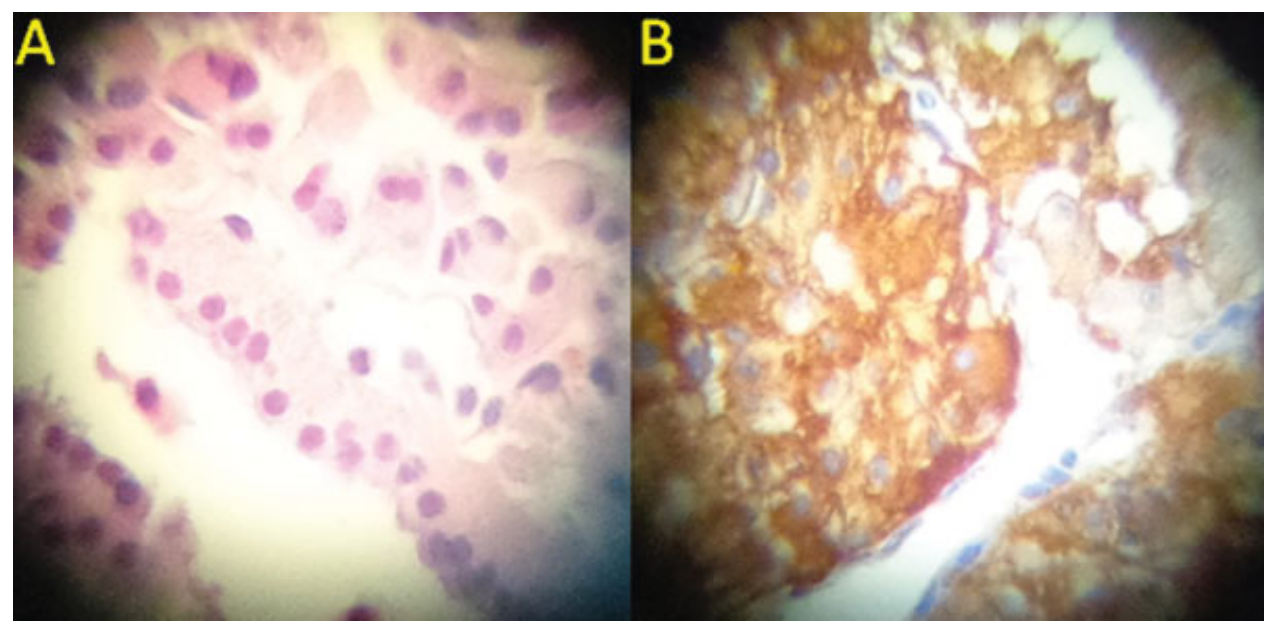

Fig. 2 Pathological findings. (A) Histologic features of thyroid carcinoma in hematoxylin-eosin staining. (B) Immunohistochemistry revealing intense tireoglobulin staining, a typical finding of Hürthle cell carcinoma.

\section{Discussion}

Thyroid cancer bone metastases frequently cause significant morbidity. ${ }^{1,2}$ They may be present at the initial diagnosis in up to $50 \%$ of patients. ${ }^{2}$ Spread of thyroid carcinoma to bone is more common in patients older than 45 years and is characteristically symptomatic and multicentric. ${ }^{2}$ In one series, the vertebrae, pelvis, ribs, and femur were respectively the most common sites of metastases. Multiple lesions were present in $53 \%$ of the cases. The overall 10 -year survival rate from the time of diagnosis of thyroid cancer was $35 \%$, and from diagnosis of initial bone metastasis was $13 \%{ }^{2}$

Hürthle cell carcinoma is a rare variant of differentiated thyroid cancer characterized by solid tumor nests and microfollicle formation, sometimes with abundant colloid production and strong immunocytochemical reactivity for thyroglobulin., ${ }^{3,4}$ Even in the presence of metastases, patients with Hürthle cell carcinoma usually have a relatively good prognosis, being considered the most favorable histologic subtype for survival. ${ }^{3}$

Few other reports disclosed Hürthle cell carcinoma as spinal metastasis, and none with sacral involvement. ${ }^{3-5}$ We highlight our case once it approaches a young woman presenting with atypical symptomatology of low back pain as first clinical presentation of a solitary sacral bone metastatic Hürthle cell carcinoma.

\section{Conflict of Interest}

The authors declare no conflicts of interest.

\section{References}

1 Farooki A, Leung V, Tala H, Tuttle RM. Skeletal-related events due to bone metastases from differentiated thyroid cancer. J Clin Endocrinol Metab 2012;97(7):2433-2439

2 Pittas AG, Adler M, Fazzari M, et al. Bone metastases from thyroid carcinoma: clinical characteristics and prognostic variables in one hundred forty-six patients. Thyroid 2000;10(3):261-268

3 Sciubba DM, Petteys RJ, Kang S, et al. Solitary spinal metastasis of Hürthle cell thyroid carcinoma.J Clin Neurosci 2010;17(6):797-801

4 Heimann A, Moll U. Spinal metastasis of a thyroglobulin-rich Hürthle cell carcinoma detected by fine needle aspiration. Light and electron microscopic study of an unusual case. Acta Cytol 1989;33(5):639-644

5 Demura S, Kawahara N, Murakami H, et al. Total en bloc spondylectomy for spinal metastases in thyroid carcinoma. J Neurosurg Spine 2011;14(2):172-176 